\title{
Congenital Kyphosis
}

National Cancer Institute

\section{Source}

National Cancer Institute. Congenital Kyphosis. NCI Thesaurus. Code C35325.

An abnormally increased curvature of the thoracic portion of the spine that is present at the time of birth. 